Bull. Fac. Agric., Cairo Univ., 64: 87-95 (2013).

\title{
CHARACTERISTICS OF PHOSPHOROUS SORPTION BY SOME NATURAL SEDIMENTS OF SAUDI ARABIA
}

(Received: 21.10.2012)

\author{
By \\ A. S. Al-Farraj, S. E. El-Maghraby, A. Sh. Sallam, and M. I. Al-Wabel \\ Soil Science Department, College of Food and Agriculture Sciences, \\ King Saud University, Saudi Arabia
}

\begin{abstract}
The adsorption of phosphate is a process wherein phosphate ions in solution react with atoms on the surface of soil particles. This is an important property affecting both the fate of phosphate fertilizer and the availability of phosphate to plants. In order to understand this phenomena, two natural (gray and red) clay sediments which numerously present in Saudi Arabia, were selected to investigate the behavior of phosphorus sorption as a function of equilibrium $P$ concentration $(0,10.0,20.0,40.0,80.0$ and $100 \mu \mathrm{g} \mathrm{p} / \mathrm{ml})$. The used sediments were dominated by smectite clay with relatively small amounts of calcite and kaokinite. The average clay content in the used sediments ranged from 64 to $73 \%$, while the $\mathrm{CaCO}_{3}$ ranged from 16 to $22 \mathrm{~g}$. $\mathrm{kg}^{-1}, \mathrm{EC}_{\mathrm{e}}\left(20.19\right.$ to $\left.37.31 \mathrm{dSm}^{-1}\right)$, and $\mathrm{pH}$ (7.02 to 7.14). Clay fractions were separated from sediment samples have CEC $\left(\mathrm{C}\right.$ mole $\left.\mathrm{kg}^{-1}\right)$ range between 56 and 71.5 and surface area of $128-690 \mathrm{~m}^{2} \mathrm{gm}^{-1}$. Results indicated that the phosphorus sorption followed the Langmuir adsorption isotherm. Moreover, the Freundlich adsorption isotherm was also, applicable over the entire $\mathrm{P}$ concentration range (0 to $100 \mu \mathrm{g} \mathrm{p} / \mathrm{ml})$. Data pertaining the Langmuir adsorption isotherm show that, the binding energy $\left(\mathrm{K}_{\mathrm{d}}\right)$ reached 51.34 and $2.30 \mathrm{l} / \mathrm{gm}$ for the $1^{\text {st }}$ and the $2^{\text {nd }}$ steps of $\mathrm{P}$ sorbed by the gray clay sediment, respectively. While the respective values for the red clay reached 33.76 and $2.63 \mathrm{l} / \mathrm{gm}$. Meanwhile, for the Freundlich adsorption isotherm, the binding energy $(\mathrm{n})$ reached 0.58 and $0.53 \mathrm{l} / \mathrm{gm}$ for the gray and red clay sediments, respectively. However, the $\mathrm{b}$ values (maximum adsorption capacity) reached 47.04 and $130.59 \mathrm{mg} / \mathrm{g}$ with correlation coefficient $\left(\mathrm{r}^{2}\right) 0.98$ and 0.95 for the gray and red sediments, respectively. Desorption data indicated that nearly half of the adsorbed $\mathrm{P}$ was extracted in the two extractions which followed the adsorption. In conclusion, the study emphasized the high impacts of the used natural clay deposits in phosphorus retention and such deposits can be successfully used to provide the growing plants with available phosphorus through $\mathrm{p}$ fertilizations.
\end{abstract}

Key words: clay deposits, langmuir and freundlich adsorption isotherms, phosphorous adsorption.

\section{INTRODUCTION}

From the lecture it is well known that soils have a defined capacity to adsorb phosphorus and there will be a great possibility to release excess $\mathrm{P}$ into the surface or ground water when a critical $\mathrm{P}$ sorption saturation level is attained (Paulter and Sim, 2000 and Bohn et al., 2011). Moreover, phosphate sorption plays an important role in environmental aspects of $\mathrm{P}$ management. The capacity of soil to retain added $\mathrm{P}$ is often described by simple adsorption equations, which relate $\mathrm{P}$ concentration in solution to the amount of $\mathrm{P}$ retained by the soil (Jalali and Peikam, 2012). The most popular mathematical models used to describe $\mathrm{P}$ sorption are the Langmuir and Freundlich equations (Afsar et al., 2012). Many studies indicated that the most soil properties affecting the $\mathrm{P}$ adsorption capacity are soil texture (Leclerc et al., 2001) organic matter (Daly et al., 2001), oxides of iron and aluminium (Toor et al., 1997), soil $\mathrm{pH}$ and $\mathrm{CaCO}_{3}$ content (Bertrand et al.,2003).

As the soil solution contains low concentration of $\mathrm{P}$ as compared to plant requirements, many trials have been done for predicting the quantity of phosphate fertilizer required to bring soil to various levels of adequacy for crop production. An approach to this problem is to measure adsorbed phosphate at standard supernatant concentrations of $\mathrm{P}$ as an 
estimate of phosphate needs of soils. Phosphate adsorption isotherms have been used as basis for evaluating the $\mathrm{P}$ requirements of soils (Fox and Malat 1993). However, investigations of phosphate adsorption have been centered on two major areas, namely the mechanism of phosphate adsorption and the identification of phosphate reactive sites (Yuan and $\mathrm{Wu}, 2007)$. Understanding $\mathrm{P}$ adsorption mechanism is vital for improving efficiency of phosphate fertilizer use while the latter is essential to evaluate intensity of adsorption and understanding the various processes associated with the phenomenon.

Mineral deposits in Saudi Arabia are widespread and of many types, all conditions favorable for the formation and accumulation of clay deposits were combined during the Phanerozoic in Saudi Arabia (Laurent, 1993). In most cases, the clay occurrences in such deposits contain a predominant proportion of kaolinite. Exceptions are the distinctly marine deposits of the early Paleozoic (Jauf and Tauk formations) and the Tertiary littoral marine deposits of the east coast (Hadrukh and Dam formations) in which illite predominates. Certain lagoon or lacustrine environments generated deposits of attapulgite clay (Aruma and Dammam formations) or montmorillonitic clay (Tertiary formations of the Red Sea coast) (Laurent, 1993). Natural clays such as clay stone or mudstone comprise several clay minerals with one or more impurities. The most common impurities are free iron oxide minerals, amorphous silica and alumina, quartz grain, limestone, gypsum and other more soluble salts. These impurities affect largely clay characteristics and may affect adversely its use in specific applications (Al-Omran et al., 2004 and AlOmran et al., 2005). In their study Fox and Malat, (1993) pointed out that a kinetic study, of phosphate adsorption showed an initial fast step followed by a slower process affecting by $\mathrm{pH}$, phosphate concentration, rate of shaking and temperature, they added that desorption of phosphate also revealed two consecutive kinetic stages. In addition, clay minerals, such as kaolinite, illite, beidellite, and montmorillonite which constitute the fine-grained part of the ore, have a tendency to fix large proportions of the extractor, depending upon their surface properties (Zhou and $\mathrm{Li}, 2011$ ). It is interesting to note that the natural sediments were found in a huge quantities and have been used for long times to sustain agricultural productivity in
Saudi Arabia (Al-Omran et al., 2005and Sheta et al., 2006). Therefore, the objective of this study was to investigate the kinetics of phosphorus adsorption / desorption by such natural sediments to establish a good management practice for $\mathrm{P}$ fertilizer under Saudi Arabian conditions.

\subsection{Sediment collections}

Two natural clay sediments (gray and red) were collected from the South Western Regions of Saudi Arabia. The gray sediments were collected from Jeddah-Al- Madinah Al-Munawwarah road which located at $\left(\begin{array}{lllllll}39^{\circ} & 13^{\prime} & 53.1^{\prime \prime} & \mathrm{E}, 22^{\circ} & 13^{\prime} & 53^{\prime \prime} & \mathrm{N}\end{array}\right)$, meanwhile the red sediments were collected from Khulays Governorate located at ( $39^{\circ} 2^{\prime} 31.6^{\prime \prime} \mathrm{E}$, $22^{\circ} 9^{\prime}$ 9.2" N).

The collected sediments were prepared for mineralogical, physical and chemical analyses following the standard procedures described by Gee and Bauder,(1996) for particle size distribution; Rhoades, (1996) and Thomas, (1996) for soluble salts and $\mathrm{pH}$ determination in the saturation paste extract; Loeobert and Suarez (1996) for the determination of calcium carbonate content. Cation exchange capacity in each soil sample was determined with the method for arid zone soils described by Sumner et al. (1996). Surface area was measured according to Soil Survey Laboratory Methods Manual, (1992). Tables (1 and 2) depict some of the physico- chemical and mineralogical properties of the studied deposits collected from different locations.

The clay fraction $(<2$ um) was separated from the collected sedements according to (Soukup et al., 2008). Sub samples of clay fraction were $\mathrm{Mg}^{2+}$ or $\mathrm{K}^{+}$saturated using $1 \mathrm{M} \mathrm{MgCl}_{2}$ or $1 \mathrm{M} \mathrm{KCl}$, respectively, then slides were prepared as oriented mounts. X-ray diffractograms were obtained using $\mathrm{Cu}-\mathrm{K} \alpha$ radiation at $40 \mathrm{kV}$ and $25 \mathrm{~mA}$. K-saturated samples were scanned after air drying and following heat treatment at $550^{\circ} \mathrm{C}$ for $2 \mathrm{~h}$. Mg-saturated samples were scanned following air drying and ethylene glycol solvation. Identification of clay minerals and accessory minerals was carried out according to (Dixon and Weed, 1989). Free iron and manganese oxides $\left(\mathrm{Fe}_{\mathrm{d}} \& \mathrm{Mn}_{\mathrm{d}}\right)$ were extracted using sodium citrate bicarbonate- dithionate method (CBD) according to (Mehra and Jackson, 1960). Amorphous silica and alumina $\left(\mathrm{Si}\right.$ am $\left.\& \mathrm{Al}_{\mathrm{am}}\right)$ were dissolved in boiled $\mathrm{NaOH}(1 \mathrm{~N})$ for 2.5 minutes 
according to Alexiades \& Jackson (1966) then Al and $\mathrm{Si}$ in the extracts were measured by Atomic Absorption.

\subsection{Phosphorus adsorption experiments}

Two grams from each of the clay deposits were placed in $100 \mathrm{ml}$ polypropylene centrifuge tubes and solutions $(20 \mathrm{ml})$ containing varying amounts of $\mathrm{P}$ $(0,10.0,20.0,40.0,80.0$ and $100.0 \mu \mathrm{g} \mathrm{P} / \mathrm{ml}$ in $\mathrm{P}$ free $0.03 \mathrm{M}$ potassium nitrate $\left(\mathrm{KNO}_{3}\right)$ at $\mathrm{pH} 7.0$, were added and the resulting suspensions were allowed to attain equilibrium for $24 \mathrm{~h}$ at $25^{\circ} \mathrm{C}$ in an incubator with occasional shaking followed by centrifugation $\left(15000 \mathrm{rpm}\right.$ for $15 \mathrm{~min}$, at $25^{\circ} \mathrm{C}$ ), then decantation, and filtration. The filtrate was analyzed for P following the methods of Olsen and Sommers, (1982). The equilibrium solution was prepared by dissolving potassium dihydrogen phosphate $\left(\mathrm{KH}_{2} \mathrm{PO}_{4}\right)$. Dilute $\mathrm{KNO}_{3}$ solution was used instead of de ionized water or dilute calcium chloride solution to avoid a positive error due to presence of yellowish color in the water extract or a possible $\mathrm{P}$ retention in presence of high contents of soluble calcium in the form of $\mathrm{Ca}$ - Phosphate minerals. $\mathrm{P}$ sorped by the studied clay deposits was calculated as the difference between the initial $\mathrm{P}$ and equilibrium $\mathrm{P}$ concentrations. The amount of native adsorbed $\mathrm{P}$ initially present in the deposits was estimated by extrapolating the adsorption isotherms derived from higher to zero concentration of soluble $\mathrm{P}$ and from the amount of $\mathrm{P}$ extracted with $\mathrm{P}-$ free $0.01 \mathrm{M} \mathrm{CaCl}_{2}$ solution. The native $\mathrm{P}$ so estimated was taken into account to establish the corrected adsorption isotherm. The data of $\mathrm{P}$ sorption were first calculated according to Langmuir adsorption isotherm. The linear form of the isotherm used was: $(\mathrm{c}) /(\mathrm{X} / \mathrm{m})=1 / \mathrm{b} \quad(\mathrm{c})+1 / \mathrm{kb}$, Where $(\mathrm{c})=$ equilibrium concentration $(\mu \mathrm{g} \mathrm{p} / \mathrm{ml}),(\mathrm{x} / \mathrm{m})=$ adsorbed $\mathrm{p}(\mu \mathrm{g} \mathrm{p} / \mathrm{g}$ soil $), \mathrm{b}=$ adsorption maximum ( $\mu \mathrm{g} \mathrm{p} / \mathrm{g}$ soil), and $\mathrm{k}=\mathrm{a}$ constant related to bonding energy $(\mathrm{ml} / \mu \mathrm{g})$. The data were also described by the Freundlich adsorption isotherm. The linear form of the isotherm used was: $\log (\mathrm{X} / \mathrm{m})=1 / \mathrm{n} \log (\mathrm{c})+$ $\log \mathrm{k}$, where $1 / \mathrm{n}$ is the slope of the regression line, and $\mathrm{k}$ and $\mathrm{n}$ are empirical constants.

\subsection{Phosphorus desorption experiments}

Each of the previously used deposit samples in the adsorption experiments was treated two more successfully times with $10 \mathrm{ml}$ of $\mathrm{P}$ - free $0.5 \mathrm{M}$ $\mathrm{NH}_{4} \mathrm{HCO}_{3}$ DTPA solution, and shoked for $24 \mathrm{~h}$ followed by centrifugation for $15 \mathrm{~min}$ at $3000 \mathrm{rpm}$. The supernatants were collected for the $\mathrm{P}$ determination using the method described by Olsen and Sommers (1982). Desorbed P was calculated as the difference between the equilibrium $P$ concentrations at each desorption step and the equilibrium $\mathrm{P}$ concentrations of the previous step, divided by two (dilution factor). A statistical analysis including simple and multiple correlation coefficients were made to determine if any relationship existed between various deposit properties and some $\mathrm{P}$ adsorption / desorption parameters among the studied clay deposits.

\section{RESULTS AND DISCUSSION \\ 3.1. Properties of the used sediments}

The studied clay deposits are exposed on gentle slopes beneath the stony layers. Table (1) showed that the studied sediment has clay content ranges from 64 to $73 \%$, very high clay content was recorded in the first site (Gray sediments). $\mathrm{CaCO}_{3}$ contents range from 16 to $22 \mathrm{~g} \mathrm{~kg}^{-1}$. Salinity levels are quite high and range from $20.19-37.31 \mathrm{dS} \mathrm{m}^{-1}$. Values of sediment's $\mathrm{pH}$ ranged from 7.02 to 7.14, which corresponded to most of the arid soils. The studied sediments have relatively high contents of total $\mathrm{Fe}$ particularly in the sediment samples from Al-Madinah (Nos. 41 and 42) $132.5 \mathrm{gkg}^{-1}$ where the sediments were formed from the basaltic lava of the Harrat. Total contents of $\mathrm{P}$ in the studied sediments are variable between 1.8 and $2.7 \mathrm{mg} \mathrm{kg}^{-1}$ (Table 2). On the other hand, the available $\mathrm{P}$ ranges from $1.5-$ $2 \mathrm{mg} \mathrm{kg}^{-1}$.

The results presented in Table (2) indicated that free $\mathrm{Fe}$ oxides ranged from $19399-25986 \mathrm{mg} \mathrm{kg}^{-1}$. The highest contents were observed in the second samples (Khulays Governorate). Free Mn oxides showed relatively high quantities which ranged from 131-139 mg kg-1 which could reflect the mineralogical composition of the dominant igneous and metamorphic rocks from which these deposits were formed.

The Cation exchange capacity was quite high for the studied samples and ranged from 56 to 71.5 $\mathrm{C}$ mole $\mathrm{kg}^{-1}$ (Table 2). The studied clays have high surface area; it ranges from 128.4- $371.4 \mathrm{~m}^{2} \cdot \mathrm{gm}^{-1}$ which was quite high. X-ray diffract grams showed, the dominance of smectite followed by kaolinite, illite, and interstratified minerals.

\subsection{Phosphorus adsorption}

The $\mathrm{P}$ sorption by the studied clay sediments generally, conformed to the Langmuir sorption isotherm but over limited concentration ranges. 
Table (1): Location, sample description and some characteristics of the collected sediment samples.

\begin{tabular}{|c|c|c|c|c|c|}
\hline \multirow{2}{*}{ Sample } & \multirow{2}{*}{ Location } & \multicolumn{2}{|c|}{ Color } & \multirow[t]{2}{*}{ pH } & \multirow{2}{*}{$\begin{array}{c}\mathrm{EC} \\
\mathrm{dS} \mathrm{m}^{-1}\end{array}$} \\
\hline & & Dry & Moist & & \\
\hline $\begin{array}{c}\text { Gray } \\
\text { deposits }\end{array}$ & $\begin{array}{l}\text { Jeddah-Al-Madinah } \\
\text { Al-Munawwarah Road } \\
39^{\circ} 13^{\prime} 53.1^{\prime \prime} \text { E, } 2^{\circ} 13^{\prime} \\
53^{\prime \prime} \mathrm{N}\end{array}$ & $\begin{array}{c}\text { Light gray } \\
(2.5 Y 7 / 2)\end{array}$ & Pale yellow (2.5Y 7/4) & 7.02 & 37.31 \\
\hline $\begin{array}{c}\text { Red } \\
\text { deposits }\end{array}$ & $\begin{array}{l}\text { Khulays Governorate } \\
39^{\circ} 2^{\prime} \quad 31.6^{\prime \prime} \text { E, } 22^{\circ} 9^{\prime} \\
9.2^{\prime \prime} \mathrm{N}\end{array}$ & $\begin{array}{c}\text { Yellowish } \\
\operatorname{red}(5 Y \text { R5/6) }\end{array}$ & $\operatorname{Red}(2.5 Y R 4 / 6)$ & 7.14 & 20.19 \\
\hline
\end{tabular}

\begin{tabular}{|c|c|c|c|c|c|}
\hline Sample & $\mathrm{CaCO}_{3}(\mathrm{~g} / \mathrm{kg})$ & Clay $(\%)$ & Silt $(\%)$ & Sand (\%) & Description \\
\hline Gray deposits & 22 & 73 & 17 & 10 & Clayey clods, gray, compacted \\
\hline Red deposits & 16 & 64 & 23 & 13 & Clayey clods, red, compacted \\
\hline
\end{tabular}

Table (2): Amorphous Si and Al, Free Fe and Mn oxides, surface area, cation exchange capacity (CEC), and semi quantitative analysis of X-ray diffract grams obtained for clay fraction separated from sediment samples.

\begin{tabular}{|c|c|c|c|c|c|c|c|c|}
\hline \multirow{2}{*}{\multicolumn{2}{|c|}{ Sample }} & \multirow{2}{*}{$\begin{array}{c}\text { CEC } \\
\text { Cmole kg }^{-1}\end{array}$} & $\mathbf{M n} \mathbf{n}_{\mathrm{d}}$ & $\mathbf{F e}_{\mathrm{d}}$ & $\mathbf{S i}_{\mathrm{at}}$ & $\mathbf{A l}_{\mathrm{ar}}$ & \multirow{2}{*}{\multicolumn{2}{|c|}{$\begin{array}{c}\text { Surface Area } \\
\mathrm{m}^{2} \mathrm{gm}^{-1}\end{array}$}} \\
\hline & & & \multicolumn{4}{|c|}{ mg kg-1 } & & \\
\hline \multicolumn{2}{|c|}{ Gray deposits } & 71.5 & 139.2 & 19399 & \multicolumn{2}{|c|}{1630} & \multicolumn{2}{|r|}{690} \\
\hline \multicolumn{2}{|c|}{ Red deposits } & 56.0 & 131.3 & 25986 & \multicolumn{2}{|c|}{1341} & \multicolumn{2}{|r|}{128.4} \\
\hline \multicolumn{9}{|c|}{ Where: $\mathrm{Al}_{\mathrm{am}}$ : amorphous alumina, $\mathrm{Si}_{\mathrm{am}}$ amorphous silica, $\mathrm{Fe}_{\mathrm{d}}$ free Fe oxides, $\mathrm{Mn}_{\mathrm{d}}$ Free Mn oxides } \\
\hline Sample & Smectite & Kaolinit & \multicolumn{3}{|c|}{ Interstratified } & IIllite & Quartz & Feldspars \\
\hline $\begin{array}{c}\text { Gray } \\
\text { deposits }\end{array}$ & ++++ & ++ & \multicolumn{3}{|c|}{+} & + & + & + \\
\hline $\begin{array}{c}\text { Red } \\
\text { deposits }\end{array}$ & +++ & +++ & \multicolumn{3}{|c|}{+} & + & ++ & + \\
\hline
\end{tabular}

Where: ++++ means $(>70 \%),+++(50-70 \%),++(35-50 \%),+(10-35 \%)$

However, at high equilibrium solution data deviated from the Langmuir model. Such deviations from the Langmuir model indicated that there were different reactions may be occur at higher $\mathrm{P}$ concentrations (Table, 3 and Figs. 1 \&2). The obtained $\mathrm{K}$ values reflected the large difference between the two studied sediments in their C.E.C and their specific surface area ( Tables, $1 \& 2$ ).

The gray sediments with relatively high clay and $\mathrm{CaCO}_{3}$ contents had adsorbed more phosphate. Such behavior could be either owing to large surface area of gray sediment or stronger reactive sites (Tables, 1 \& 2). In this respect, Leclerc et al., (2001) recorded higher adsorption maxima with greater clay contents of soils, while Bertrand et al. (2003) supported that calcium carbonate enhanced phosphate adsorption.

Using the $\mathrm{R}^{2}$ values as a test for goodness of fit gray as well as red sediments $\left(\mathrm{R}^{2}=99\right)$ appeared to conform relatively well to Langmuir equation especially in the $1^{\text {st }}$ and the $2^{\text {nd }}$ stages of adsorption (Table 3 and Fig. 1). This indicating that phosphate adsorption did not occur by a single process in these sediments. Thus, Langmuir equation can be used to characterize the $\mathrm{p}$ adsorption. In this respect, some workers suggested that adsorption follows Langmuir isotherm in the range of 25-100 $\mathrm{ug} \mathrm{g}^{-1}$ of adsorbed $\mathrm{P}$ (Paulter and Sim, 2000; Bohn et al., 2011). Afsar et al. (2012) considered the effect of adsorbed ions in the equilibrium solution as the cause of the commonly reported curvilinear nature of the simple Langmuir isotherm.

Freundlich equation was applied to the same $\mathrm{P}$ adsorption data by plotting logarithmic values of $\mathrm{x} / \mathrm{m}$ (the adsorbed $\mathrm{P}$ ) against values of $\log \mathrm{C}_{\mathrm{n}}$ (the 
equilibrium $\mathrm{P}$ concentration). Also, due to $\mathrm{R}^{2}$ value Freundlich equation described adequately phosphate retention by the studied sediments (Table 4). Freundlich equation showed another characteristic that the adsorption points were compressed at the top end, which might have disguised the poor linearity. In this respect, Barrow (1978) reported gentle curves when Freundlich equation was applied to soil phosphate adsorption data.

\subsection{Amounts of desorbed Phosphorus}

Studying phosphorus desorption may be helpful for better understanding the role of the studied sediments in providing the adsorbed phosphorus fertilizers to the growing plants. This is because the availability of both applied and native phosphorus is largely controlled by sorption and desorption characteristics of the soil. Therefore, a proper understanding of the mechanism of $\mathrm{P}$ release from the used sediments is very important to establish good management practices for P fertilizations.

Higher amounts of extracted $\mathrm{P}$ were obtained in the second extraction from the two studied sediments; Also, Gray clay sediments gave the higher amounts of extracted P. This behavior may be due to the nature of adsorbing sites in such deposits, which may differ from those of the other red clay one. By calculating the desorbed $\mathrm{P}$ as a percentage from the adsorbed $\mathrm{P}$, one can conclude that, the studying clay deposits were greatly differ from each other, especially at low concentration of applied P. Furthermore, the relatively higher percentages of desorbed $\mathrm{P}$ were obtained in the $1^{\text {st }}$ extraction which followed the adsorption. The differences in such percentages were (35.48-32.18); $(43.03$ - 38.73) ; (37.71 - 30.308); (41.49- 27.97) and ( $44.49-33.51)$ for the gray sediments, while the respective values for the red deposits reached (28.26- 25.27); (33.97- 30.43); (34.32- 29.23); (47.07-35.20) and (45.39-34.23), respectively.

The obtained results lead to the conclusion that the amount of adsorbed Phosphate ions increase as the rate of applied phosphate increased from 0 to $100 \mathrm{mg} / \mathrm{l}$ in the two tested sediment samples. Data agreed very well with the Langmuir and Freundlich equation, as the correlation coefficient was almost near 1.0 for the two studied sediments. In the

Table (3): Maximum adsorption capacity (MAC) and binding energy (BE) for the adsorbed Phosphorus on the studying sediments according to Langmuir equation.

\begin{tabular}{|c|c|c|c|c|c|}
\hline Deposit & Step & Equation & $\mathbf{R}^{2}$ & $\begin{array}{c}\text { (MAC) } \\
\text { b (mg/g) }\end{array}$ & $\mathbf{K} \stackrel{(B E)}{(1 / g m)}$ \\
\hline \multirow[b]{2}{*}{ Gray clay } & $\mathbf{1}^{s t}$ & $\mathrm{C} /(\mathrm{x} / \mathrm{m})=6.0683 \mathrm{X}+0.1182$ & 0.99 & 0.165 & 51.339 \\
\hline & $2^{\text {nd }}$ & $\mathrm{C} /(\mathrm{x} / \mathrm{m})=1.4268 \mathrm{X}+0.6212$ & 0.99 & 0.701 & 2.297 \\
\hline \multirow{2}{*}{ Red clay } & $\mathbf{1}^{s t}$ & $\mathrm{C} /(\mathrm{x} / \mathrm{m})=5.5264 \mathrm{X}+0.1637$ & 0.99 & 0.181 & 33.759 \\
\hline & $\mathbf{2}^{\text {nd }}$ & $\mathrm{C} /(\mathrm{x} / \mathrm{m})=1.5803 \mathrm{X}+\mathbf{0 . 6 0 0 5}$ & 0.99 & 0.633 & 2.632 \\
\hline
\end{tabular}

Table (4): Maximum adsorption capacity (MAC) and binding energy (BE) for the adsorbed Phosphorous on the studying sediments according to Frundlish equation.

\begin{tabular}{|l|c|l|c|c|}
\hline Deposit & Equation & $\mathbf{R}^{2}$ & $\begin{array}{c}(\mathrm{BE}) \\
\mathbf{n} \\
\mathbf{1 / g m}\end{array}$ & $\begin{array}{c}\text { (M AC) K } \\
\mathrm{mg} / \mathrm{g}\end{array}$ \\
\hline Gray clay & $\log (\mathrm{x} / \mathrm{m})=1.7197 \mathrm{x}-1.6725$ & $\mathbf{0 . 9 8}$ & $\mathbf{0 . 5 8 1 4}$ & $\mathbf{4 7 . 0 4 3 5 4}$ \\
\hline Red clay & $\log (\mathrm{x} / \mathrm{m})=1.887 \mathrm{x}-2.1159$ & $\mathbf{0 . 9 5}$ & $\mathbf{0 . 5 2 9 9}$ & 130.587 \\
\hline
\end{tabular}


Langmuir adsorption the $\mathrm{K}_{\mathrm{d}}$ values for the used sediments reached 51.34 and $2.30 \mathrm{l} / \mathrm{gm}$ for the $1^{\text {st }}$ and the $2^{\text {nd }}$ steps of gray clay, respectively. While for the red clay reached 33.76 and $2.63 \mathrm{l} / \mathrm{gm}$. However, the maximum adsorption capacity reached 0.165 and $0.53 \mathrm{mg} / \mathrm{g}$ with correlation coefficient $\left(\mathrm{r}^{2}\right)$ 0.99 and 99, respectively. Meanwhile, for the Freundlich adsorption isotherm, the binding energy (n) reached 0.58 and $0.53 \mathrm{l} / \mathrm{gm}$ for the gray and red clay sediments, respectively. However, the $b$ values (maximum adsorption capacity) reached 47.04 and $130.59 \mathrm{mg} / \mathrm{g}$ with correlation coefficient $\left(\mathrm{r}^{2}\right) 0.98$ and 0.95 for the gray and red sediments, respectively.

Desorption data indicated that nearly half of the adsorbed $\mathrm{P}$ was extracted in the two extractions which followed the adsorption. In conclusion, the ability of the used clay sediments to retain $\mathrm{P}$ was high and there were differences between the studied sediments in sorption and desorption characteristics of $\mathrm{P}$. This indicates the profitability of using both studied natural sediments as ion exchangers for phosphorus sorption as well as, providing the growing plants with available phosphorus through $\mathrm{p}$ fertilizations.

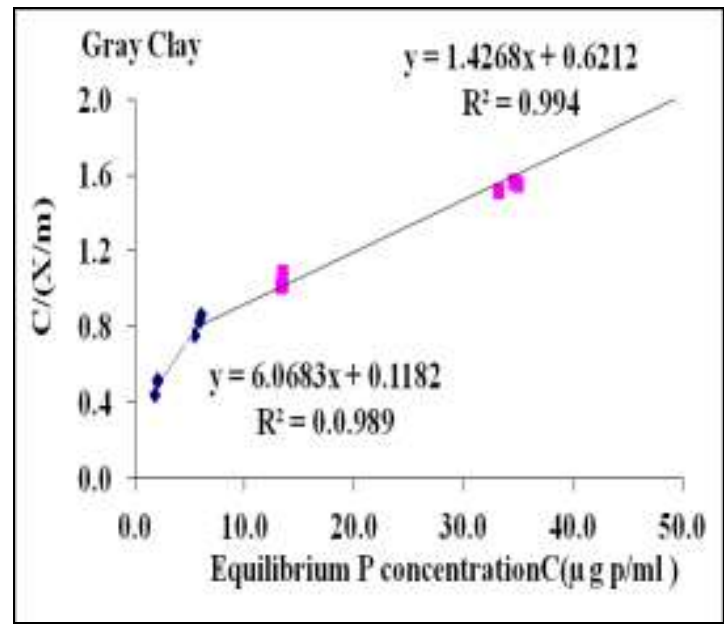

Fig. (1): Langmuir adsorption isotherm of $P$ in the studying Gray Sediments.

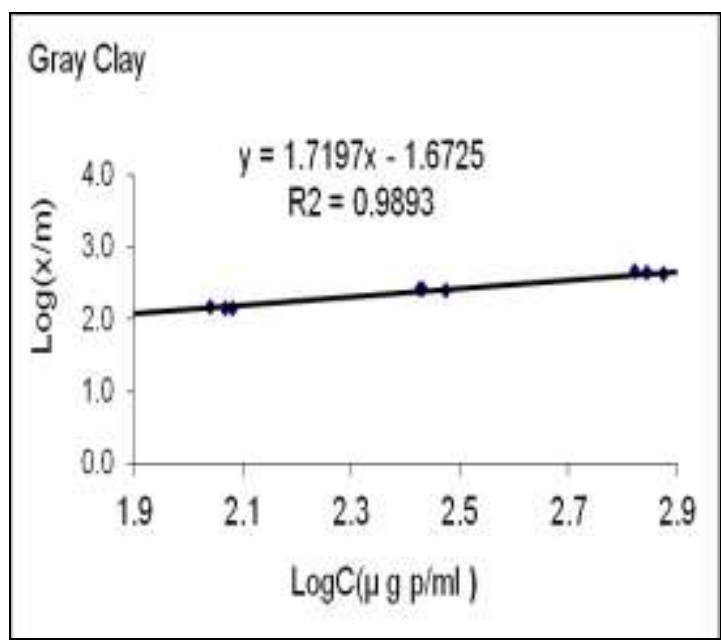

Fig. (3): Freundlich adsorption isotherm of $P$ in the studying Gray Sediments.

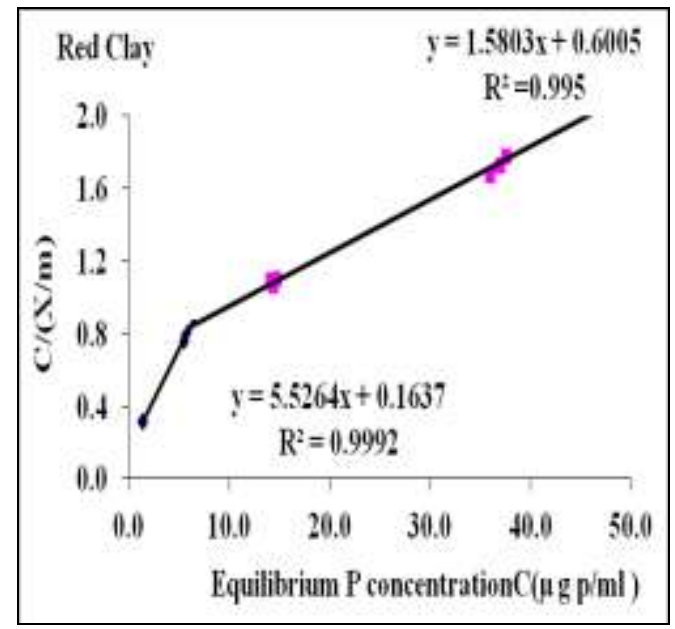

Fig. (2):Langmuir adsorption isotherm of $P$ in the studying Red Sediments.

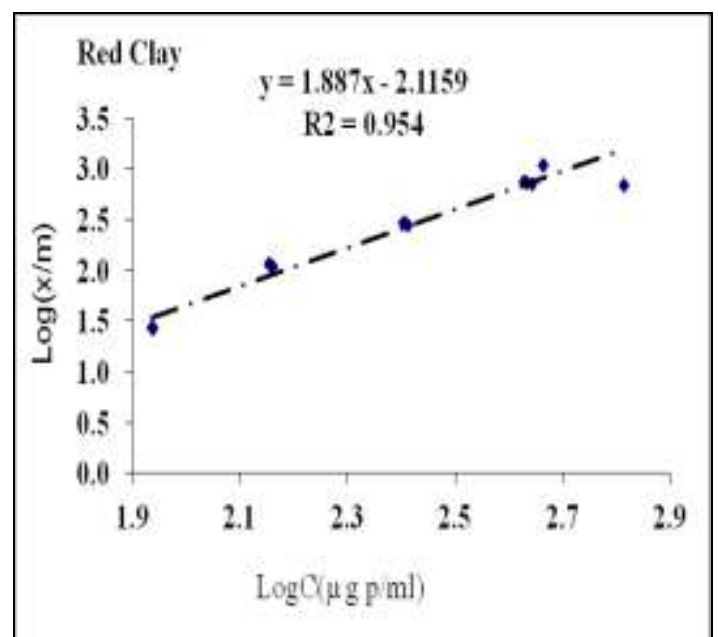

Fig.(4): Freundlich adsorption isotherm of $P$ in the studying Red Sediments. 
Table (5): Desorbed $P$ as a percentage from its adsorption on the studied sediments.

\begin{tabular}{|c|c|c|c|c|c|c|c|c|}
\hline \multirow{2}{*}{$\begin{array}{c}\text { Applied } \\
\text { P (mg/l) }\end{array}$} & \multirow{2}{*}{$\begin{array}{c}\mathrm{Ce} \\
(\mathrm{mg} / \mathrm{l})\end{array}$} & \multirow{2}{*}{$\begin{array}{r}\mathbf{X} / \mathbf{m} \\
(\mathrm{mg} / \mathrm{g})\end{array}$} & \multicolumn{3}{|c|}{ Desorbed $P(\mathrm{mg} / \mathrm{g})$} & \multicolumn{3}{|c|}{ Desorbed / Adsorbed \% } \\
\hline & & & D1 & D2 & Total & D1 & D2 & Total \\
\hline \multicolumn{9}{|c|}{ Gray Clay Sediments } \\
\hline $\mathbf{0}$ & 0.00 & 0.000 & 0.013 & 0.011 & 0.024 & 0.000 & 0.000 & 0.000 \\
\hline 10.0 & 1.96 & 0.080 & 0.041 & 0.037 & 0.078 & 35.478 & 32.181 & 67.659 \\
\hline 20.0 & 5.78 & 0.142 & 0.074 & 0.066 & 0.140 & 43.030 & 38.734 & 81.764 \\
\hline 40.0 & 13.89 & 0.261 & 0.111 & 0.090 & 0.202 & 37.713 & 30.308 & 68.021 \\
\hline 80.0 & 35.21 & 0.448 & 0.199 & 0.136 & 0.335 & 41.490 & 27.972 & 69.461 \\
\hline 100.0 & 50.99 & 0.490 & 0.231 & 0.175 & 0.406 & 44.490 & 33.508 & 77.998 \\
\hline \multicolumn{9}{|c|}{ Red Clay Sediments } \\
\hline $\mathbf{0}$ & 0.00 & 0.000 & 0.009 & 0.006 & 0.015 & 0.000 & 0.000 & 0.000 \\
\hline 10.0 & 1.35 & 0.086 & 0.033 & $\mathbf{0 . 0 2 8}$ & 0.061 & 28.262 & 25.267 & 53.529 \\
\hline 20.0 & 5.64 & 0.143 & 0.058 & 0.050 & 0.107 & 33.974 & 30.434 & 64.407 \\
\hline 40.0 & 14.39 & 0.256 & 0.097 & 0.081 & 0.178 & 34.315 & 29.232 & 63.548 \\
\hline 80.0 & 36.86 & 0.431 & 0.212 & 0.158 & 0.370 & 47.074 & 35.195 & 82.269 \\
\hline 100.0 & 47.48 & 0.525 & 0.247 & 0.186 & 0.433 & 45.393 & 34.232 & 79.626 \\
\hline
\end{tabular}

\section{REFERENCES}

Afsar M. Z., Hoque S. and Osman K. T.,(2012). “A Comparison of the Langmuir, Freundlich and Temkin Equations to Describe Phosphate Sorption Characteristics of Some Representative Soils of Bangladesh," International Journal of Soil Science,.7, (3):91-99.

Alexiades C., and Jackson M. L. (1966). Quantitative clay mineralogical analysis of soil and sediments. Clays and Clay Minerals, 14: 35 .

Al-Omran A. M., Falatah A. M., Sheta A. S. and AlHarbi A. R..(2004) "Clay deposits for water management of sandy soils". Arid Land Research and Management 18, No.2,171-183.

Al-Omran A.M., Sheta A.S., Falatah A.M. and AlHarbi A.R. (2005). Effect of drip irrigation on squash (Cucurbita pepo) yield and water use efficiency in sandy calcareous soils amended with clay deposits. Agricultural Water Management73:43-55.

Barrow N. J. (1978). The description of phosphate adsorption curves. J. Soil Sci. 29: 447-462.

Bertrand I., Holloway R. E., Armstrong R. D.and MCLaughlin M. J. (2003). "Chemical Characteristics of Phosphorus in Alkaline Soils from Southern Australia," Australian Journal of Soil Research,(41): 61-76.

Bohn H. L., McNealand B. L. and O'Connor G. A. (2011). "Soil Chemistry," (3rd ed.), John Wiley and Sons Inc., USA, 2011.
Daly K., Jeffrey D. and Tunney H. (2001). "The Effect of Soil Type on Phosphorus Sorption Capacity and Desorption Dynamics in Irish Grassland Soils," Soil Use Management, (17): 12-20.

Dixon J. B. and Weed S. B. (1989). (eds.) Minerals in Soil environments. Soil. Sci. Soc. Am.,2nd ed., Madison, Wisconsin, USA.

Fox I. and Malat M. A. (1993). An investigation of phosphate adsorption by clays and its relation to the problems of eutrophication of the river stour, Kent. Journal of Chemical Technology \& Biotechnology. (2): 97-107.

Gee G. W. and Bauder J. W. (1996). Particle-size analysis. In: A. Klute (ed.) Methods of soil analysis. Part 1. Physical and mineralogical methods. 2nd ed. Agronomy Monograph 9:383-411. SSSA Book Series: 5, Am. Soc. of Agron., Inc. Madison, WI.

Jalali M. and Peikam E. N. (2012). "Phosphorus Sorption-Desorption Behavior of River Bed Sediments in the Abshineh River, Hamedan, Iran, Related to their Composition," Environmental Monitoring and Assessment, doi:10.1007/s10661-012-2573-5.

Laurent D. (1993). Kingdom of Saudi Arabia Atlas of Industrial Minerals. Saudi Arbia, Ministry of Petroleum and Mineral Resources, Directorate General of Mineral Resources, Jeddah, Saudi Arabia (pp:7-10).

Leclerc M. L., Nolin M. C., Cluis D. and Simard R. R. (2001). "Grouping Soils of the Montreal 
Lowlands (Quebec) According to Fertility and $\mathrm{P}$ Sorption and Desorption Characteristics," Canadian Journal of Soil Science, ( 81): 71-83.

Loeobert R. H. and Suarez D. L. (1996). Carbonate and Gypsium. In: D. L. Spark (ed.) Methods of soil analysis. Part 3. Chemical methods. Agronomy Monograph 5:437 -470. Am. Soc. of Agron., Inc. Madison, WI.

Mehra O.P. and Jackson M. L. (1960). "Iron oxide removal from soils and clays by a dithionite citrate- bicarbonate system buffered with sodium bicarbonate". Clays Clay Miner. 7:317-327.

Olsen S. R. and Sommers L.E. (1982). Phosphorus, pp. 403 - 431, In A. L. Page et al., (eds.) Methods of Soil Analysis. Part 2, $2^{\text {ed }}$ ed., Agron. 9, Amer. Soc. of Agron. Inc., Madison, WI. USA..

Paulter M. C. and J. T. Sims, (2000)."Relationships between Soil Test Phosphorus, Soluble Phosphorus and Phosphorus Saturation in Delaware Soils," Soil Science Society of America Journal, (64):765-773.

Rhoades J. D. (1996). Salinity: Electrical Conductivity and Total Dissolved Solids. In D. L. Spark (ed.) Methods of soil analysis. Part 3. Chemical methods. Agronomy Monograph 5:417 -435.

Sheta A. S., Al-Omran A. M., Falatah A. M., Sallam A. Sh. and Al-Harbi A.R. (2006). Characteristics of Natural Clay Deposits in Saudi Arabia and Their Potential Use for Nutrients and Water Conservation. J. King Saud Univ., Vol. 19, Agric. Sci. (1), : 25-38.
Soil Survey Laboratory Methods Manual. (1992). Soil Survey Investigations Report No. 42. U. S. Department of Agriculture, Washington, DC. Pp393-395.

Soukup D. A., Buck B. J.and Harris W. (2008). Preparing Soil for Mineralogical Analyses. In: A. L. Ulery \& L. R. Drees (eds.) Methods of soil analysis - Part 5: Mineralogical Methods ( $3^{\text {rd }}$ ed).Soil Science Society of America., Inc. Madison, WI. 13-32.

Sumner M. E. and Miller W. P. (1996). Cation Exchange Capacity and Exchange Coefficients. In: D. L. Spark (ed.) Methods of soil analysis. Part 3. Chemical methods. Agronomy Monograph, 5: 1220-1221. Am. Soc. of Agron., Inc. Madison, WI.

Thomas G. W. (1996). Soil pH and Soil Acidity. In: D. L. Spark (ed.) Methods of soil analysis. Part 3. Chemical methods. Agronomy Monograph 5:475 -490. Am. Soc. of Agron., Inc. Madison, WI.

Toor G. S., Bahl G. S. and. Vig A. C (1997). "Pattern of P Availability in Different Soils as Assessed by the Adsorption Equations," Journal of Indian Society of Soil Science, Vol. 45, pp. 719-723.

Yuan G., and Wu L. (2007). Allophane nanoclay for the removal of phosphorus in water and wastewater. Science and Technology of Advanced Materials. 8:60-62.

Zhou K. and Li Y. (2011). "Phosphorus-Sorption Characteristics of Soils and Limestone from the Southern Everglades and Adjacent Farmlands," Soil Science Society of America Journal, (65):1404-1412.

\section{خصائص إدمصاص الفوسفور على بعض الرواسب الطبيعية بالمملكة العربية السعودية \\ عبد الله بن سليمان الفراج -سالم العزب المغربي- عبد العظيم شهوان سلام - عحمد بن إبراهيم الوابل \\ قسم علوم التربة ـ كلية علوم الأغذية والزر اعة ـ جامعة الملك سعودـ المملكة العربية السعودية}

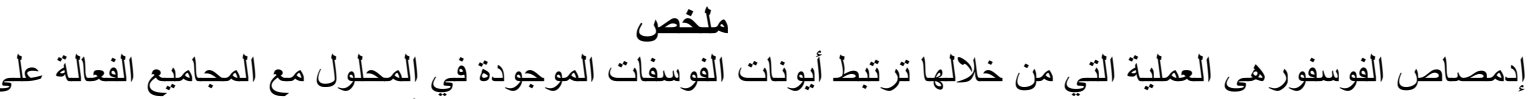

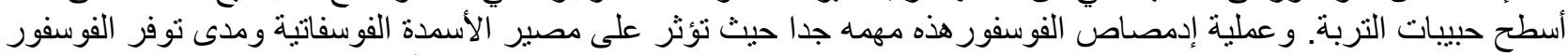

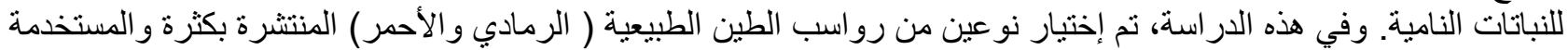

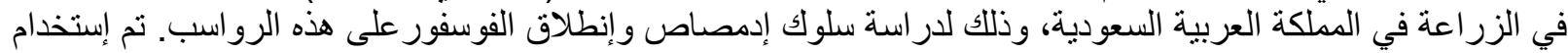

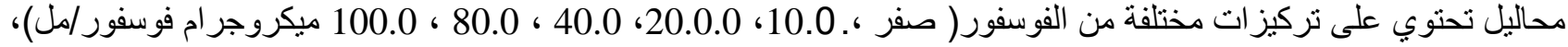
وذلك للتعرف على سلوك إدمصاصيها على النو عين المذكورين من الرو اسب بتطبيق معادلتي لانجماير وفريندليش للإدمصاص ، 
و أيضا تمت در اسة سلوك إنطلاق الفوسفور المدمص بو اسطة الرواسب المختارة. أوضحت تحليلات عينات الرواسب المستخدمة

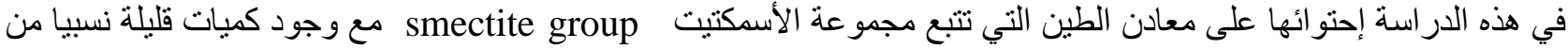

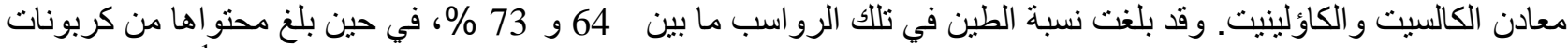
الكالسيوم 16 من 16 إلى 22 جم/ كجم، وقيم التوصيل الكهربي

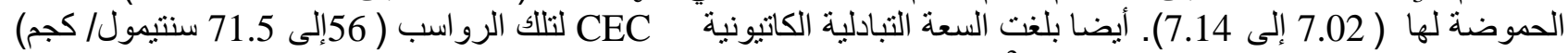

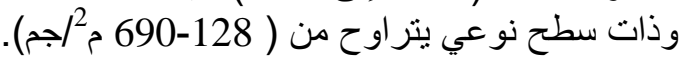

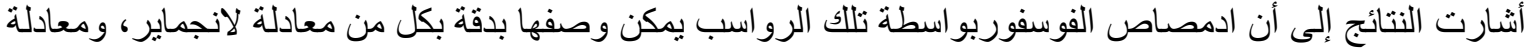

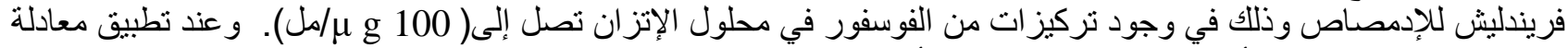
لانجماير للإدمصاص لبادمداصين أن طاقة إرتباط الفوسفور بأسطح رواسب الطين الرمادية المستخدمة بلغت (

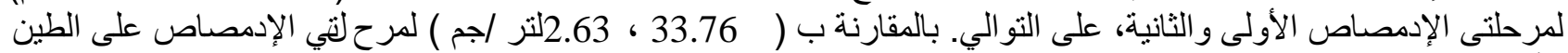
الأحمر . في حين بلغت السعة الإدمصاصية القصوى للفوسفور ( (R²)

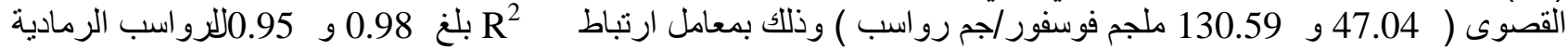

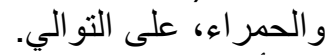

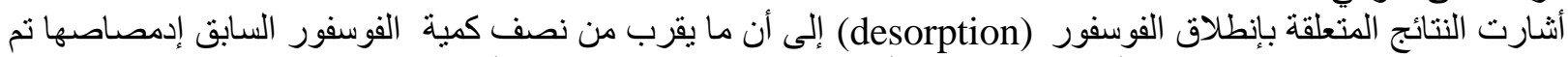

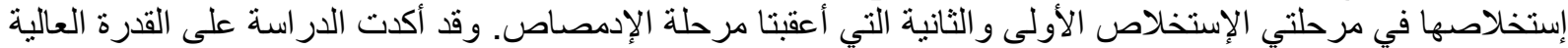

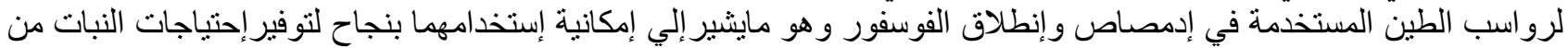
المجلة العلمية - لكلية الزراعة - جامعة القاهرة (المجلا64) العلا الأول ( يناير 2013):95-87. 